This content is available online at AESA
e-ISSN: $2456-6632$

\title{
Effect of variety and spacing on the yield performance of maize (Zea mays L.) in old Brahmaputra floodplain area of Bangladesh
}

\author{
Md. Rezwanul Hasan ${ }^{1}$, Md. Rashedur Rahman ${ }^{1^{*}}$ (D) , Ahmed Khairul Hasan ${ }^{1}$, Swapan Kumar Paul ${ }^{1}$ \\ and A.H.M. Jahangir Alam²
}

${ }^{1}$ Department of Agronomy, Bangladesh Agricultural University, Mymensingh, BANGLADESH

${ }^{2}$ Department of Agricultural Extension (DAE), Khamarbari, Dhaka, BANGLADESH

"Corresponding author's E-mail: mrrahmanbau@gmail.com

\section{ARTICLE HISTORY}

Received: 02 July 2018

Revised received: 04 August 2018

Accepted: 14 August 2018

\section{Keywords}

Old Brahmaputra floodplain

Maize varieties

Planting spacing

Yield attributes and yield

\section{ABSTRACT}

The experiments were conducted at the Agronomy Field Laboratory, Agricultural University, Mymensingh in Bangladesh during December 2015 to April 2016 to investigate the effect of variety and plant spacing on yield attributes and yield of maize. The experiment comprised of five varieties viz., Khoi bhutta, BARI hybrid maize 7, BARI hybrid maize 9, C-1921, P-3396 and five plants spacing viz., $75 \mathrm{~cm} \times 20 \mathrm{~cm}, 75 \mathrm{~cm} \times 25 \mathrm{~cm}, 75 \mathrm{~cm} \times 30 \mathrm{~cm}, 75 \mathrm{~cm} \times 35 \mathrm{~cm}$ and $75 \mathrm{~cm}$ $\times 40 \mathrm{~cm}$. The experiment was laid out in a randomized complete block design with three replications. Results revealed that variety and plant spacing had significant effect on the studied crop characters and yield. The highest plant height, highest number of leaves plant ${ }^{-1}$, longest cob, maximum diameter of cob, highest number of kernel $\mathrm{cob}^{-1}$, the highest 1000 -grain weight, maximum grain yield and stover yield were observed in BARI hybrid maize 7 . On the other hand, the shortest plant, lowest number of cob, diameter of cob, lowest number of grains $\mathrm{cob}^{-1}$, 1000 -grain weight, grain yield and stover yield were observed in Khoi bhutta. The longest plant, highest cob, maximum diameter of cob, highest number of kernel $\mathrm{cob}^{-1}$ the highest 1000grain weight, maximum grain yield and stover yield was observed in the spacing of $75 \mathrm{~cm} \times 25$ $\mathrm{cm}$. In contrast, the spacing of $75 \mathrm{~cm} \times 30 \mathrm{~cm}$ produced the lowest values of the above mentioned plant parameters and also showed the lowest grain yield. In regard to interaction effect of variety and spacing, the highest plant height $(232.67 \mathrm{~cm})$, maximum number of cob plant ${ }^{-1}$ (1.73), maximum diameter of $\mathrm{cob}(4.60 \mathrm{~cm})$, highest number of kernel $\mathrm{cob}^{-1}(34)$, maximum stover yield $\left(12.38 \mathrm{t} \mathrm{ha}^{-1}\right)$ were observed at the spacing of $75 \mathrm{~cm} \times 25 \mathrm{~cm}$ with BARI hybrid maize 7 and resulting in the highest grain yield $\left(9.04 \mathrm{t} \mathrm{ha}^{-1}\right)$. The lowest values of the above parameters were recorded in the narrowest plant spacing of $75 \mathrm{~cm} \times 35 \mathrm{~cm}$ with Khoi bhutta. Based on the experimental results, it may be concluded that maize (cv. BARI hybrid maize 7) can be cultivated with a spacing of $75 \mathrm{~cm} \times 25 \mathrm{~cm}$ for appreciable grain yield.

(C)2018 Agriculture and Environmental Science Academy

Citation of this article: Hasan, M.R., Rahman, M.R., Hasan, A.K., Paul, S.K. and Alam, A.H.M.J. (2018). Effect of variety and spacing on the yield performance of maize (Zea mays L.) in old Brahmaputra floodplain area of Bangladesh. Archives of Agriculture and Environmental Science, 3(3): 270-274, https://dx.doi.org/10.26832/24566632.2018.0303010

\section{INTRODUCTION}

Maize (Zea mays L.) is one of the most important cereal crops of the world and hence it may be acceptable as third cereal crop in Bangladesh for its higher productivity (FAO, 2012). In Bangladesh, it covers about 0.35 million hectares of land producing 2.3 million metric tons grains (BBS, 2016; Zamir et al., 2011). Its demand is increasing day by day as various food items, fodder for livestock, and feed for poultry, fuel and raw materials for industry (Tajul et al., 2013). Maize can be consumed directly as green cob, roasted cob or popped grain. Its grain can be used for human consumption in various ways, such as corn meal, fried 
grain and flour. Its grain has high nutritive value containing $66.2 \%$ starch, $11.1 \%$ protein, $7.12 \%$ oil and $1.5 \%$ minerals. Moreover, it contains $90 \mathrm{mg}$ carotene, $1.8 \mathrm{mg}$ niacin, $0.8 \mathrm{mg}$ thiamin and $0.1 \mathrm{mg}$ riboflavin per $100 \mathrm{~g}$ grains (Chowdhury and Islam, 1999). Maize oil is used as the best quality edible oil. Green parts of the plant and grain are used as livestock and poultry feed, respectively. Stover and dry leaves are used as good fuel (Ahmed, 1994). Maize has a great utility in agro-industry for the production of corn syrup, soft drink, juice, beer, chewing gum, candy, chips, corn flakes and starch. So, maize can contribute in food and nutritional security program in Bangladesh because of its higher productivity and nutritional value. The average yield of maize in the country is not satisfactory. It is rather very low compared with leading maize growing countries of the world. The national average yield is only $6.45 \mathrm{t}$ $\mathrm{ha}^{-1}$, whereas, the newly released varieties have the potential to produce more than $8.0 \mathrm{t} \mathrm{ha}^{-1}$ (AIS, 2015).

Plant variety and planting spacing usually affect crop environment, which influence crop growth and yield. Maize varieties have great impact on yield. Hybrid varieties produce more than double than local varieties. Cultivation of hybrid varieties along with various planting spacing can increase production of maize. Adjustment of proper plant spacing in the maize field is important to ensure maximum utilization of solar energy by the crop and reduce evaporation of soil moisture (FAO, 2012). Radiation intercepted by the leaf surface and the efficiency or its use in developing biomass govern the total dry matter production. Population levels should be sustained to exploit maximum natural resources, such as nutrients, sunlight, soil moisture etc. and to ensure satisfactory yield. Very closest planting is undesirable because it encourages inter-plant competition for resources. Biomass production of a crop largely depends on the function of leaf area development and consequential photosynthetic activity (Natr, 1992). Thus different varieties and appropriate plant spacing have to be ensured with a view to maximizing maize yield. With the above view, an experiment was carried out to study the effect of variety and spacing on the yield performance of maize in old Brahmaputra floodplain area.

\section{MATERIALS AND METHODS}

\section{Description of experimental site}

The experiments were performed at the Agronomy Field Laboratory, Bangladesh Agricultural University, Mymensingh in the December 2015 to April 2016. The experimental site is located at $24^{\circ} 75^{\prime} \mathrm{N}$ latitude and $90^{\circ} 50^{\prime} \mathrm{E}$ longitude in the south -west part of Brahmaputra at an elevation of $18 \mathrm{~m}$ above the sea level. This site belongs to non-calcareous dark grey floodplain soil under the agro-ecological zone Old Brahmaputra Floodplain "AEZ-9" (UNDP and FAO, 1988).

\section{Experimental design}

The experiment was done in a randomized complete block design with three replications having five varieties viz., Khoi bhutta, BARI hybrid maize 7, BARI hybrid maize 9, C-1921, P-3396 and five plant spacing viz., $75 \mathrm{~cm} \times 20 \mathrm{~cm}, 75 \mathrm{~cm} \times 25$ $\mathrm{cm}, 75 \mathrm{~cm} \times 30 \mathrm{~cm}, 75 \mathrm{~cm} \times 35 \mathrm{~cm}$ and $75 \mathrm{~cm} \times 40 \mathrm{~cm}$. the whole area was divided into 3 blocks and then each block was subdivide into 25 plots. The size of the unit plot was $9 \mathrm{~m}^{2}(3 \mathrm{~m} \times$ $3 \mathrm{~m})$ and thus the total number of plots were 75 . The distance between plots were one meter.

\section{Raising of experimental crops}

The land was prepared with power tiller ploughed for several times until it got the desirable tilth condition. Then the plots were prepared according to the design of the treatments. The plots were fertilized with Urea, TSP (Triple super phosphate), MoP (Muriate of potash), Gypsum and $\mathrm{Zn} \mathrm{SO}_{4}$ at the rate of 500, 240, 180, 240 and $10 \mathrm{~kg} / \mathrm{ha}$, respectively. The total amount of TSP, MP, Gypsum and $\mathrm{ZnSO}_{4}$ were broadcasted and incorporated to the soil at final land preparation. First $1 / 3^{\text {rd }}$ of urea was applied at final land preparation. The rest of the urea were top dressed in 2 installments: $1 / 3^{\text {rd }}$ at 25 DAS and the other $1 / 3^{\text {rd }}$ at 45 DAS. Seeds were sown on 12 December, 2015 as per experimental spacing apart by opening 3-4 cm deep furrows with tine. Two seeds were sown in each hill ${ }^{-1}$. Weeding was done at 25 DAS and 55 DAS. Only one healthy seedling hill ${ }^{-1}$ was kept and the rest were thinned out at 14 DAS. The crop was irrigated two times at 40 and 80 DAS.

\section{Observation and data collection}

Five plants were randomly selected from each plot for collecting data on yield attributes and yield. At full maturity, the crop was harvested plot-wise on 16 April, 2016. Cobs were dried in bright sunshine, shelled and the grains were cleaned properly. Grains and stalk were thoroughly dried plot by plot individually before their weights were recorded. Grains obtained from each unit plot were sun-dried to $14 \%$ moisture and weighed carefully and the plot yield was recorded in metric tons per hectare $\left(\mathrm{t} \mathrm{ha}{ }^{-1}\right)$. Stalks obtained from each unit plot were dried in sun and final stalk yield per plot was recorded in $\mathrm{t} \mathrm{ha}^{-1}$. Harvest index (\%) was calculated using the following formula:

Harvest index $(\%)=\frac{\text { Economic yield }(\text { Grain yield })}{\text { Biological yield }(\text { Grain yield }+ \text { Stover yield })} \times 100$

Statistical analysis of data

Data were compiled and tabulated in proper form for statistical analysis. The recorded data were statistically analyzed to find out the significance of variation resulting from the experimental treatments. All the collected data were analyzed and adjudged by Duncan's Multiple Range Test.

\section{RESULTS AND DISCUSSION}

\section{Crop characteristics and yield attributes}

The number of leaves plant ${ }^{-1}$, rows $\operatorname{cob}^{-1}$, kernel $\operatorname{cob}^{-1}$, and thousand grain weights were significantly influenced by various varieties (Table 1). The highest number of leaves plant ${ }^{-1}$ was 
observed in BARI hybrid maize 9 (15.6) and the lowest number of leaves was observed in Khoi Bhutta (12.0) (Table 1). Highest number of rows $\mathrm{cob}^{-1}(16.00)$ was found in BARI hybrid maize 7 and the lowest number of rows $\operatorname{cob}^{-1}(12.00)$ was obtained in P-3396 (Table 1). The highest number of kernel cob $^{-1}$ (35.49) was found in khoi bhutta and the lowest number of kernel cob ${ }^{-1}$ (28.00) was obtained with P-3396 (Table 1). The highest thousand-grain weight (351.33 g) was obtained from BARI hybrid maize 9 and the lowest thousand-grain weight (155.00 g) achieved with khoi bhutta (Table 1). A similar result was also reported Zamir et al. (2011). They have used two hybrids maize varieties $\mathrm{H} 1$ (30 Y 87) and H 2 (31 R 88) having density levels $\mathrm{S}$ $1(15 \mathrm{~cm}), \mathrm{S} 2(20 \mathrm{~cm}), \mathrm{S} 3(25 \mathrm{~cm})$ and $\mathrm{S} 4(30 \mathrm{~cm})$ were sown at row spacing of $60 \mathrm{~cm}$. The hybrid $30 \mathrm{Y} 87$ was early in maturity, produced more number of cobs per plant, more number of grain rows per cob, less number of grains per row and less cob length than the hybrid $31 \mathrm{R} 88$. Similarly 1000 -grain weight, grain yield and straw yield of hybrid $\mathrm{H} 1$ (30 Y 87) was significantly greater than the hybrid H 2 (31 R 88 Although narrow plant spacing (15, $20 \mathrm{~cm}$ ) caused substantial reduction in yield components such as grains/cob, number of cobs/plant and 1000-grain weight compared to the wide plant spacing $(30 \mathrm{~cm})$ yet it gave the maximum yield $\left(7.69 \mathrm{t} \mathrm{ha}^{-1}\right)$ against the minimum of $\left(5.01 \mathrm{t} \mathrm{ha}^{-1}\right)$ in the latter.

Spacing had a significant effect on leaves plant ${ }^{-1}$, cobs plant ${ }^{-1}$, rows $\mathrm{cob}^{-1}$, kernel $\mathrm{cob}^{-1}$, thousand-grain weight. The highest leaves plant ${ }^{-1}$ (15.67) was obtained from $75 \mathrm{~cm} \times 20 \mathrm{~cm}$ spacing the lowest number of leaves (12.00) was found with $75 \mathrm{~cm} \times 35$ $\mathrm{cm}$. (Table 2). The highest number of cobs plant ${ }^{-1}$ (1.73) was obtained from $75 \mathrm{~cm} \times 20 \mathrm{~cm}$ spacing and the less number of cobs plant $^{-1}$ (1.33) was recorded at a spacing of $75 \mathrm{~cm} \times 40 \mathrm{~cm}$ (Table 2). The highest rows $\operatorname{cob}^{-1}$ (16.00) was obtained from 75 $\mathrm{cm} \times 20 \mathrm{~cm}$ spacing and $75 \mathrm{~cm} \times 35 \mathrm{~cm}$ spacing produced lowest (Table 2). The plants grown in $75 \mathrm{~cm} \times 25 \mathrm{~cm}$ spacing produced the highest number of kernel $\mathrm{cob}^{-1}$ (34.00) and the lowest number of kernel $\operatorname{cob}^{-1}$ (29.33) was produced when the crop was sowing at $75 \mathrm{~cm} \times 40 \mathrm{~cm}$ (Table 2). Thousand-grain weight differs with plant spacing. Maximum thousand-grain weight ( $351.33 \mathrm{~g}$ ) was observed in $75 \mathrm{~cm} \times 30 \mathrm{~cm}$ spacing which was similar with $75 \mathrm{~cm} \times 20 \mathrm{~cm}$ spacing and $75 \mathrm{~cm} \times 40 \mathrm{~cm}$ spacing produced lowest (Table 2). The lowest values for yield attributes in closer spacing were due to high competition for the resources such as sun light, moisture, nutrient and air. Similar trend was reported elsewhere (Dawadi and Sah, 2012). They have conducted an experiment National Maize Research Program Farm, Rampur, Nepal and found that plant density of 66,666 plants/ha produced the higher grain yield (11.19 t/ha) compared to that of 55,555 plants/ha (9.52 t/ha). However, grain yield at 66,666 plants/ha did not show a significant difference with that of 83,333 plants/ha (10.54 t/ha). Increasing plant density from 55,555 plants/ha to 83,333 plants/ha had increased the stover yield, whereas, the Harvest Index $(\mathrm{HI})$ and grain stover ratio were not significantly influenced by plant densities. Similarly, $200 \mathrm{~kg} / \mathrm{ha} \mathrm{N}$ application produced a higher grain yield (10.9 t/ ha) than $120 \mathrm{~kg} / \mathrm{ha} \mathrm{N}$ application (9.76 t/ha), but was in par with $160 \mathrm{~kg} / \mathrm{ha} \mathrm{N}$ application (10.59 t/ha).

Table 1. Effect of variety on the crop characters and yield contributing characters of maize.

\begin{tabular}{lcccccc}
\hline Variety & $\begin{array}{c}\text { Plant height } \\
\text { (cm) }\end{array}$ & $\begin{array}{c}\text { Leaves plant }^{-1} \\
\text { (no.) }\end{array}$ & $\begin{array}{c}\text { Cobs plant } \\
\text { (no.) }\end{array}$ & $\begin{array}{c}\text { Rows } \\
\text { cob }^{-1} \text { (no.) }\end{array}$ & $\begin{array}{c}\text { Kernel cob }^{-1} \\
\text { (no.) }\end{array}$ & $\begin{array}{c}\text { 1000-Grain } \\
\text { weight (g) }\end{array}$ \\
\hline Khoi Bhutta & 217.0 & $12.0 \mathrm{c}$ & 1.47 & $15.00 \mathrm{~d}$ & $35.49 \mathrm{a}$ & $155.00 \mathrm{bc}$ \\
BARI hybrid maize 7 & 209.0 & $14.0 \mathrm{ab}$ & 1.67 & $16.00 \mathrm{a}$ & $34.00 \mathrm{~b}$ & $346.33 \mathrm{ab}$ \\
BARI hybrid maize 9 & 232.6 & $15.6 \mathrm{a}$ & 1.73 & $15.08 \mathrm{c}$ & $33.00 \mathrm{c}$ & $351.33 \mathrm{a}$ \\
C-1921 & 191.3 & $12.3 \mathrm{bc}$ & 1.60 & $15.33 \mathrm{~b}$ & $32.81 \mathrm{~d}$ & $336.33 \mathrm{ab}$ \\
P-3396 & 217.6 & $12.3 \mathrm{bc}$ & 1.40 & $12.00 \mathrm{e}$ & $28.00 \mathrm{e}$ & $329.33 \mathrm{~b}$ \\
CV (\%) & 8.51 & 7.66 & 16.98 & 6.94 & 7.01 & 4.34 \\
Level of significance & $\mathrm{NS}$ & $* *$ & $\mathrm{NS}$ & $*$ & $*$ & $*$ \\
\hline
\end{tabular}

In a column figures with same letters do not differ significantly whereas figures with dissimilar letters differ significantly (as per DMRT).

Table 2. Effect of planting spacing on the crop characters and yield contributing characters of maize.

\begin{tabular}{|c|c|c|c|c|c|c|}
\hline Spacing $(\mathrm{cm} \times \mathrm{cm})$ & $\begin{array}{l}\text { Plant height } \\
\text { (cm) }\end{array}$ & $\begin{array}{l}\text { Leaves plant } \\
\text { (no.) }\end{array}$ & $\begin{array}{l}\text { Cobs plant } \\
\text { (no.) }\end{array}$ & $\begin{array}{c}\text { Rows cob } \\
\text { (no.) }\end{array}$ & $\begin{array}{l}\text { Kernel cob } \\
\text { (no.) }\end{array}$ & $\begin{array}{c}\text { 1000-grain } \\
\text { weight }(\mathrm{g})\end{array}$ \\
\hline $75 \times 20$ & 217.67 & $15.67 a$ & $1.73 a$ & $16.00 a$ & $33.08 c$ & $351.33 a$ \\
\hline $75 \times 25$ & 227.67 & $14.67 a$ & $1.33 c$ & $15.33 b c$ & $34.00 a$ & $350.67 b$ \\
\hline $75 \times 30$ & 232.67 & 14.00ab & $1.67 a b$ & $15.33 b c$ & $33.22 b c$ & $351.33 a$ \\
\hline $75 \times 35$ & 227.67 & $12.00 \mathrm{~b}$ & $1.40 b c$ & $12.00 \mathrm{c}$ & $33.33 b$ & $346.33 c$ \\
\hline $75 \times 40$ & 224.33 & $12.33 b$ & $1.33 c$ & $15.67 b$ & $29.33 d$ & $320.00 d$ \\
\hline CV (\%) & 5.84 & 8.72 & 10.09 & 4.91 & 4.61 & 2.92 \\
\hline Level of significance & NS & $*$ & $*$ & $* *$ & * & * \\
\hline
\end{tabular}


Table 3. Interaction effect of variety and plating spacing on the crop characters and yield contributing characters of maize.

\begin{tabular}{|c|c|c|c|c|c|c|}
\hline $\begin{array}{c}\text { Interaction } \\
(\text { Variety } \times \text { Spacing })\end{array}$ & $\begin{array}{c}\text { Plant height } \\
(\mathrm{cm})\end{array}$ & $\begin{array}{l}\text { Leaves plant } \\
\text { (no.) }\end{array}$ & $\begin{array}{c}\text { Cobs plant } \\
\text { (no.) }\end{array}$ & $\begin{array}{l}\text { Rows cob }{ }^{-1} \\
\text { (no.) }\end{array}$ & $\begin{array}{l}\text { Kernel cob }{ }^{-1} \\
\text { (no.) }\end{array}$ & $\begin{array}{c}\text { 1000-Grain weight } \\
\text { (g) }\end{array}$ \\
\hline $\mathrm{V}_{1} \times \mathrm{S}_{1}$ & 196.3abcd & $10.6 \mathrm{e}$ & 1.33 & 15.00 & 33.08abc & $155.00 f$ \\
\hline $\mathrm{V}_{1} \times \mathrm{S}_{2}$ & 217.0abcd & $11.0 \mathrm{e}$ & 1.20 & 15.00 & $32.78 a b c$ & $146.33 f$ \\
\hline $\mathrm{V}_{1} \times \mathrm{S}_{3}$ & 205.3abcd & 12.0de & 1.47 & 14.33 & 33.22abc & $147.33 f$ \\
\hline $\mathrm{V}_{1} \times \mathrm{S}_{4}$ & 194.3abcd & 12.0de & 1.33 & 13.66 & 29.10ef & $149.33 f$ \\
\hline $\mathrm{V}_{1} \times \mathrm{S}_{5}$ & 204.3abcd & $11.6 \mathrm{e}$ & 1.33 & 14.33 & 31.21abcdef & $148.33 f$ \\
\hline $\mathrm{V}_{2} \times \mathrm{S}_{1}$ & 188.3bcd & 14.0de & 1.33 & 16.00 & $32.76 a b c$ & 346.333abc \\
\hline $\mathrm{V}_{2} \times \mathrm{S}_{2}$ & 200.0abcd & 13.6bcd & 1.33 & 15.33 & $34.00 \mathrm{a}$ & 344.66abcd \\
\hline $\mathrm{V}_{2} \times \mathrm{S}_{3}$ & 209.0abcd & 14.0abc & 1.67 & 14.66 & 30.51bcdef & 342.33abcde \\
\hline $\mathrm{V}_{2} \times \mathrm{S}_{4}$ & 201.0abcd & 12.0de & 1.20 & 16.00 & $33.25 a b c$ & 346.33abc \\
\hline $\mathrm{V}_{2} \times \mathrm{S}_{5}$ & 133.7e & $11.6 \mathrm{e}$ & 1.33 & 15.66 & 33.41ab & 346.33abc \\
\hline $\mathrm{V}_{3} \times \mathrm{S}_{1}$ & 211.0abcd & $15.6 a$ & 1.73 & 15.07 & 32.66abcd & 351.33a \\
\hline $\mathrm{V}_{3} \times \mathrm{S}_{2}$ & $227.6 a b$ & $14.6 a b$ & 1.33 & 14.00 & 30.66abcdef & $350.66 a b$ \\
\hline $\mathrm{V}_{3} \times \mathrm{S}_{3}$ & $232.6 a$ & $13.6 \mathrm{bcd}$ & 1.60 & 15.00 & 32.33abcde & 351.33a \\
\hline $\mathrm{V}_{3} \times \mathrm{S}_{4}$ & $227.6 a b$ & 12.0abc & 1.40 & 14.66 & $30.00 \mathrm{cdef}$ & 345.00abcd \\
\hline $\mathrm{V}_{3} \times \mathrm{S}_{5}$ & 224.3abc & 12.3cde & 1.33 & 15.00 & 32.33abcde & 343.66abcde \\
\hline $\mathrm{V}_{4} \times \mathrm{S}_{1}$ & $184.6 \mathrm{bcd}$ & $12.3 \mathrm{cde}$ & 1.60 & 14.33 & $28.33 f$ & 334.66abcde \\
\hline $\mathrm{V}_{4} \times \mathrm{S}_{2}$ & 176.3de & $12.3 \mathrm{cde}$ & 1.33 & 15.00 & 30.00cdef & 335.00abcde \\
\hline $\mathrm{V}_{4} \times \mathrm{S}_{3}$ & 191.3abcd & $12.3 \mathrm{cde}$ & 1.07 & 15.33 & 32.00abcde & 336.33abcde \\
\hline $\mathrm{V}_{4} \times \mathrm{S}_{4}$ & $182.6 \mathrm{~cd}$ & $11.6 \mathrm{e}$ & 1.33 & 14.33 & 31.00abcdef & 333.33bcde \\
\hline $\mathrm{V}_{4} \times \mathrm{S}_{5}$ & 190.0abcd & $11.6 \mathrm{e}$ & 1.33 & 15.00 & $32.80 \mathrm{abc}$ & 335.00abcde \\
\hline $\mathrm{V}_{5} \times \mathrm{S}_{1}$ & 217.6abcd & 12.3cde & 1.40 & 15.33 & 29.33def & 328.33de \\
\hline $\mathrm{V}_{5} \times \mathrm{S}_{2}$ & 215.6abcd & 12.0de & 1.33 & 14.33 & 30.33bcdef & 328.33de \\
\hline $\mathrm{V}_{5} \times \mathrm{S}_{3}$ & 200.6abcd & 12.0de & 1.40 & 15.00 & 30.66abcdef & 329.33cde \\
\hline $\mathrm{V}_{5} \times \mathrm{S}_{4}$ & 205.3abcd & $11.6 \mathrm{e}$ & 1.13 & 14.00 & 33.33abc & $328.66 \mathrm{cde}$ \\
\hline $\mathrm{V}_{5} \times \mathrm{S}_{5}$ & 201.0abcd & 12.0de & 1.07 & 14.33 & 30.66abcdef & $326.00 \mathrm{e}$ \\
\hline CV (\%) & 13.12 & 9.53 & 16.72 & 8.85 & 6.50 & 3.63 \\
\hline $\begin{array}{c}\text { Level of } \\
\text { significance }\end{array}$ & * & * & NS & NS & $*$ & $*$ \\
\hline
\end{tabular}

In a column figures with same letters do not differ significantly whereas figures with dissimilar letters differ significantly (as per DMRT); $V_{1}=$ Khoi Bhutta, $\mathrm{V}_{2}=$ BARI hybrid maize 7, $\mathrm{V}_{3}=$ BARI hybrid maize $9, \mathrm{~V}_{4}=\mathrm{C}-1921$ and $\mathrm{V}_{5}=\mathrm{P}-3396 ; \mathrm{S}_{1}=75 \mathrm{~cm} \times 20 \mathrm{~cm}, \mathrm{~S}_{2}=75 \mathrm{~cm} \times 25 \mathrm{~cm}, \mathrm{~S}_{3}=75 \mathrm{~cm} \times 30 \mathrm{~cm}$, $\mathrm{S}_{4}=75 \mathrm{~cm} \times 35 \mathrm{~cm}$ and $\mathrm{S}_{5}=75 \mathrm{~cm} \times 40 \mathrm{~cm}$.

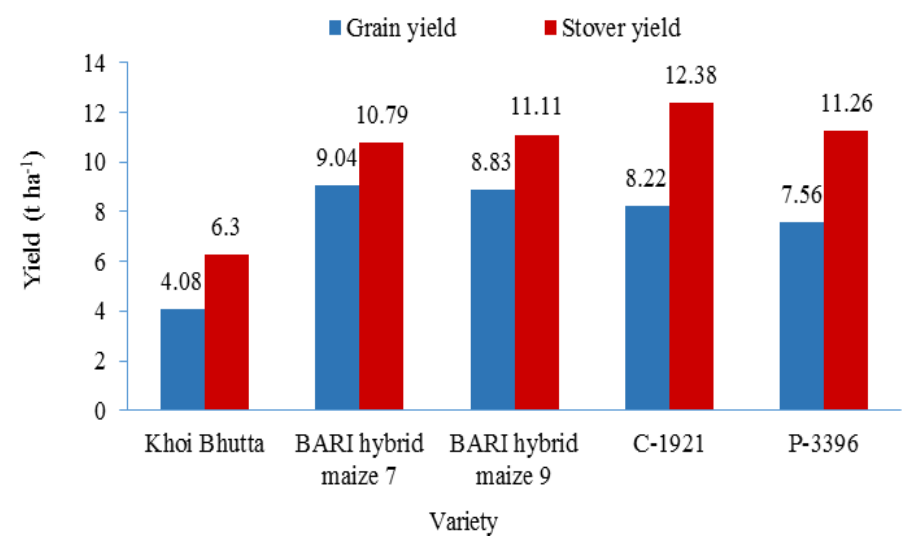

Figure 1. Effect of variety on grain yield and stover yield of maize.

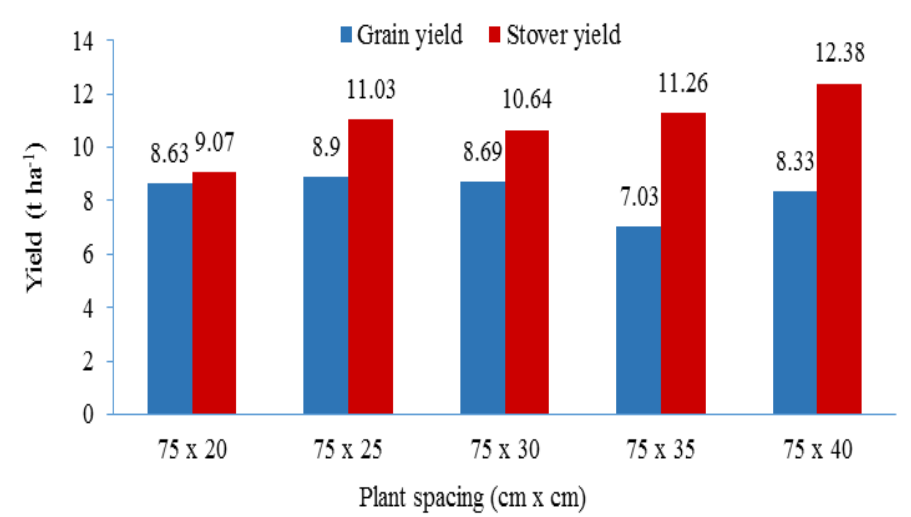

There was significant interaction effect between variety and plant spacing on plant height, leaves plant ${ }^{-1}$, cob diameter, kernel $\mathrm{cob}^{-1}$, thousand-grain weight. BARI hybrid maize 9 with $75 \mathrm{~cm} \times 30 \mathrm{~cm}$ spacing showed the tallest plant height $(232.6$ $\mathrm{cm})$ and the lowest plant height $(133.7 \mathrm{~cm})$ was recorded from BARI hybrid maize 7 with $75 \mathrm{~cm} \times 40 \mathrm{~cm}$ (Table 3). Maximum numbers of leaves (15.6) were found in BARI hybrid maize 9 with $75 \mathrm{~cm} \times 20 \mathrm{~cm}$ spacing and the lowest number of leaves plant $^{-1}$ (10.0) was obtained from Khoi bhutta with $75 \mathrm{~cm} \times 20$ $\mathrm{cm}$ spacing (Table 3 ). Maximum numbers of cob diameter were found in BARI hybrid maize 7 with $75 \mathrm{~cm} \times 20 \mathrm{~cm}$ spacing (4.60) followed by BARI hybrid maize 9 with $75 \mathrm{~cm} \times 25 \mathrm{~cm}$ spacing while the lowest was in khoi bhutta with $75 \mathrm{~cm} \times 30 \mathrm{~cm}$ (3.76) (Table 3). The highest number of rows $\operatorname{cob}^{-1}$ (16.00) was BARI hybrid maize 7 with $75 \mathrm{~cm} \times 20 \mathrm{~cm}$ spacing while the lowest (3.76) was in Khoi bhutta with $75 \mathrm{~cm} \times 30 \mathrm{~cm}$ spacing (Table 3). The highest number of kernel $\operatorname{cob}^{-1}$ (34.00) was found from BARI hybrid maize 7 with $75 \mathrm{~cm} \times 25 \mathrm{~cm}$ spacing and the lowest number of kernel cob $^{-1}$ (28.33) was obtained from C-1921 with $75 \mathrm{~cm} \times 25 \mathrm{~cm}$ (Table 3). BARI hybrid maize 9 with $75 \mathrm{~cm} \times 20$ $\mathrm{cm}$ spacing produced the highest thousand-grain weight ( $351.33 \mathrm{~g}$ ) followed by BARI hybrid maize 9 with $75 \mathrm{~cm} \times 30 \mathrm{~cm}$ spacing (351.33 g) while the lowest was in Khoi bhutta with 75 $\mathrm{cm} \times 25 \mathrm{~cm}$ spacing (146.33 g) (Table 3). 


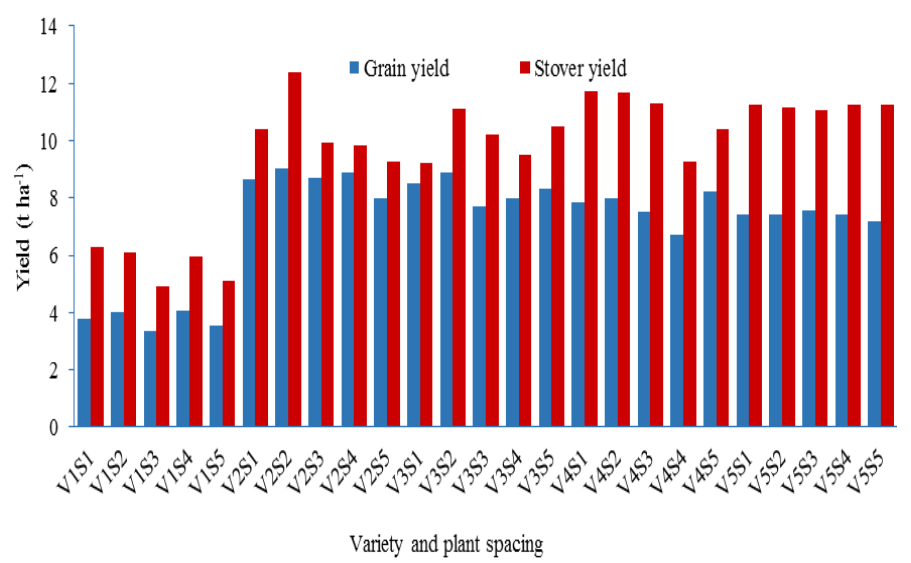

Figure 3. Interaction effect of variety and spacing on grain yield and stover yield of maize.

\section{Grain yield and stover yield}

Grain yield and stover yield were significantly influenced by variety. The highest grain yield was observed in BARI hybrid maize 7 (9.04 t ha $\left.{ }^{-1}\right)$ and the lowest grain yield was observed in khoi bhutta (4.08 $\mathrm{t} \mathrm{ha}^{-1}$ ) (Figure 1). The highest stover yield (12.38 $\mathrm{t}$ ha $\left.{ }^{1}\right)$ was obtained from C-1921 variety and the lowest stover yield $\left(6.30 \mathrm{t} \mathrm{ha}^{-1}\right)$ was produced by khoi bhutta. Considering spacing, the maximum grain yield $\left(8.90 \mathrm{tha}^{-1}\right)$ was recorded the spacing of $75 \mathrm{~cm} \times 25 \mathrm{~cm}$ and the lowest one $\left(7.03 \mathrm{t} \mathrm{ha}^{-1}\right)$ was recorded at 75 $\mathrm{cm} \times 35 \mathrm{~cm}$ spacing (Figure 2). The maximum stover yield (12.38 $\mathrm{t}$ $\mathrm{ha}^{-1}$ ) was recorded at the spacing of $75 \mathrm{~cm} \times 40 \mathrm{~cm}$ and the lowest one $\left(9.07 \mathrm{t} \mathrm{ha}^{-1}\right)$ was recorded at $75 \mathrm{~cm} \times 20 \mathrm{~cm}$ spacing.

Considering interaction effect of both variety and spacing, the highest grain yield $\left(9.04 \mathrm{t} \mathrm{ha}^{-1}\right.$ ) was found from BARI hybrid maize 7 with $75 \mathrm{~cm} \times 35 \mathrm{~cm}$ spacing followed by BARI hybrid maize 7 with $75 \mathrm{~cm} \times 25 \mathrm{~cm}$ spacing (Table 3) and the lowest one $\left(3.36 \mathrm{t} \mathrm{ha}^{-1}\right.$ ) was obtained from khoi bhutta with $75 \mathrm{~cm} \times 30 \mathrm{~cm}$ spacing (Figure 3). The highest stover yield $\left(12.38 \mathrm{t} \mathrm{ha}^{-1}\right)$ was obtained from BARI hybrid maize 7 with $75 \mathrm{~cm} \times 25 \mathrm{~cm}$ spacing and the lowest stover yield $\left(4.92 \mathrm{t} \mathrm{ha}^{-1}\right)$ were obtained from khoi bhutta with $75 \mathrm{~cm} \times 30 \mathrm{~cm}$ (Figure 3).

\section{Conclusion}

The results of this investigation concluded that plant density per unit of area of maize is much important to get a maximum yield. A high yielding variety that provides the genetic makeup of a crop, also has got the importance to get the highest yield. Based on the findings of the present study, different yield contributing characters were found significantly affected by maize varieties and also plant densities and it has been revealed that BARI hybrid maize 7 with planting at $75 \mathrm{~cm} \times 25 \mathrm{~cm}$ spacing produced best yield of maize cultivated in the old Brahmaputra floodplain area of Bangladesh.
Open Access: This is open access article distributed under the terms of the Creative Commons Attribution License, which permits unrestricted use, distribution, and reproduction in any medium, provided the original author(s) and the source are credited.

\section{REFERENCES}

Ahmed F. (1994). Maize production technology (in Bengali). Published by International Fertilizer Development CenterConsultant of Ministry of Agriculture, Bangladesh, pp. 1315.

AIS (Agriculture Information Service) (2015). Area, production and yield of different crops. Agriculture Information Service. Khamarbari, Dhaka. pp. 14.

BBS, Bangladesh Bureau of Statistics (2016). Statistical Pocketbook of Bangladesh. Statistic Division, Ministry of planning, Govt. people's Repub. Bangladesh, pp. 104.

Chowdhury, M.F. and Islam, M.A. (1999). Growth and yield component responses of maize as affected by population density. Pakistan Journal of Biological Science 2(4): 10921095.

Dawadi, D.R. and Sah, S.K. (2012). Growth and yield of hybrid maize (Zea mays L.) in relation to planting density and nitrogen levels during winter season in Nepal. Tropical Agricultural Research, 23(3): 218-227.

FAO, Food and Agriculture Organization (2012). Production report of agricultural crop 2010, http://faostat.fao.org/ site/339/default.aspx

Natr, L. (1992). Mineral nutrient a ubiquitous stress factor for photosynthesis. Indian Journal of Agronomy, 27: 271-295.

Tajul, M.I., Alam, M.M., Hossain, S.M.M., Naher, K., Rafii, M.Y. and Latif, M.A. (2013). Influence of plant population and nitrogen fertilizer at various levels on growth and growth efficiency of maize. The Scientific World Journal, 1-9: http:// doi.org/10.1155/2013/193018

UNDP, FAO (1988). Land Resources Appraisal of Bangladesh for Agricultural Development. Report 2. Agroecological Regions of Bangladesh. United Nations Development Programme and Food and Agriculture Organization, pp. 212-221.

Zamir, M.S.I., Ahmad, A.H., Javeed, M.R. and Latif, T. (2011). Growth and yield behavior of two maize hybrids (Zea mays L.) towards different plant spacing. Cercetari Agronomice in Moldova, 14(2): 33-40. http://doi.org/10.2478/v10298-012 $-0030-9$ 